\title{
MAMMARY TUMORS IN RUMINANTS
}

\author{
Sonja PRPAR MIHEVC ${ }^{1}$, Peter DOVČ ${ }^{2}$
}

Received October 15, 2013; accepted November 10, 2013. Delo je prispelo 15. oktobra 2013, sprejeto 10. novembra 2013.

\begin{abstract}
Mammary tumors in ruminants
The frequency of mammary neoplasia in different species varies tremendously. Among women, breast cancer features as one of the most frequent types of cancer globally. Breast cancer is the cause of almost half a million deaths worldwide each year. Of these deaths, more than $58 \%$ are occurring in developing countries. Mammary tumors are rare in cows, mares, goats, ewes, and sows as evident by few cases reported in literature. In dairy cattle and milking goats the udders are inspected daily by palpation when milking and the tumors would be detected soon. The morphological features of bovine mammary gland are more similar to those in human than in rodents, the latter being commonly used for cancerogenic studies. There are several factors that might affect the high rate of tumor development in women and attenuate the development of tumors in ruminants. Besides diet, life style, reproductive history, stress load, the general physiology and metabolism might have an influence. Translational research using different mammary gland cell populations from several species may lead to comparative studies and may help reduce the risk and contribute to discovery of new therapeutic targets to treat breast cancer. In present work the zero occurrence of mammary gland tumors in ruminants will be reviewed focusing on literature records and mechanisms underlying the resistance.
\end{abstract}

Key words: mammary gland / tumors / ruminants / diseases

\section{INTRODUCTION}

Since the dairy cow's udder is subjected to a cyclic growth and influenced by hormones, producing huge amounts of milk and is prone to mastitis the lack of tumors is striking. Although the average life span of a dairy cow is relatively short (6-8 years), some animals also

\section{Tumorji mlečne žleze pri prežvekovalcih}

Pogostost neoplazij v mlečnih žlezah je različna pri posameznih vrstah. Rak dojke je najbolj pogost tip raka pri ženskah. Vsako leto zaradi raka dojke umre približno pol milijona žensk. 58 \% smrti je v deželah v razvoju. Tumorji mlečne žleze so redki pri kravah, kobilah, kozah, ovcah in svinjah, na to nakazuje malo opisov v literaturi. Pri kravah mlekaricah in kozah vime otipajo vsak dan med molzenjem in bi tako tumorje hitro odkrili. Morfološko je kravja mlečna žleza bolj podobna človeški kot glodavski, čeprav slednje pogosto uporabljajo v kancerogenih študijah. Več faktorjev vpliva na razvoj tumorjev pri ženskah oziroma preprečuje nastanek tumorjev pri prežvekovalcih. Poleg prehrane, načina življenja, reproduktivne zgodovine, stesa, imata najbrž vpliv tudi splošna fiziologija in metabolizem. Primerjalne študije večih celičnih populacij iz mlečnih žlez različnih vrst, lahko vodijo k odkritju novih terapevtskih sredstev in zmanjšanju tveganja za razvoj raka. V našem delu bomo pregledali literaturo in se osredotočili na mehanizme, ki so odgovorni za nizek pojav raka v prežvekovalskih mlečnih žlezah. bolezni

Ključne besede: mlečna žleza / tumorji / prežvekovalci /

reach the age up to 15 years. Since 8 years of bovine life is equivalent to 40 years of human life (Sweet at al., 1940), many cows are allowed to live well beyond their "cancer age", which is reported to be approximately 8 years (Povey and Osborne, 1969).

Mammary tissue undergoes continuous changes throughout the lifespan of reproductively active females.

1 Univ. of Ljubljana, Biotechnical Fac., Dept. of Animal Science., Groblje 3, SI-1230, Slovenia, e-mail: sonja.prpar@bf.uni-lj.si

2 Same address as 1, e-mail: peter.dovc@bf.uni-lj.si 
Hormone induced terminal differentiation of the mammary epithelium into milk secreting lobular alveoli takes place during pregnancy and lactation (Hovey et al., 1999). Mammary gland morphogenesis involves the regulatory function of several signaling pathways, i.e. growth factors, hormones ... During the tumorigenic process the signaling is deregulated, thus allowing the mammary epithelium to expand, proliferate, and invade neighboring tissue (hyperplasia). In humans, there are about 1.38 million new cases and 458000 deaths from breast cancer each year (IARC Globocan, 2008). There are several factors associated with increased risk of breast cancer including age of menarche, first child, onset of menopause, diet, level of exercise, obesity, alcohol consumption, presence of benign breast disease, exposure to radiation, family history and genetics (McPherson et al., 2000). Recent discoveries indicate that there is a connection between normal and tumor initiating mammary stem cell (Lim et al., 2010). The extremely low incidence of mammary tumors in ruminant species in comparison with other mammalian species is a phenomenon, which deserves attention also from the medical prospective.

\section{PREVELANCE OF MAMMARY TUMORS}

Mammary gland tumors are frequent in dogs and cats, appearing extremely sporadically in other domestic animals. The dog is by far the most frequently affected domestic species. Mammary tumors represent approximately $52 \%$ of all cancers in female dogs, and $50 \%$ of them are malignant (Megalhaes, 2012). Weather caused by genetic mutations or promoted by hormones, cancers in women and domestic dogs have similar expression profiles (Munson and Moresco, 2007). Tumors of the udder can be divided into a primary group of glandular, ductal, or stromal elements; primary cutaneous tumors which directly invade the udder (e.g. melanomas or squamous cell carcinomas); and secondary metastatic tumors (e.g. lymphosarcoma) (Povey and Osborne, 1969). In contrast to domestic carnivores the incidence of mammary cancer in cattle almost equals zero.

In Table 1 the reported tumors in cattle, goats and sheep are listed. There were some additional reports found but turned out to be inadequate. Although papilloma of the skin of the teats and udder are encountered frequently in cows, goats and sheep, published surveys show a notable scarcity of mammary tumors compared to other types of bovine cancer. Ford and colleagues reported only 41 cases of mammary gland neoplasia in cattle since 1902 (Ford et al., 1989). There have been some additional cases reported since (Petrites-Murphy, 1992, Ohfuji, 2012, Chandrashekar et al., 2012). In a spontaneous case of se- cretory mammary carcinoma in cow the neoplasm was highly aggressive and malignant, neoplastic cells exhibited cytokeratin immunoreactivity, indicating the epithelial origin (Ohfuji, 2012). In addition, there have been two cattle scanning surveys conducted. First by United Stated Department of Agriculture in 1945, when they routinely inspected 13 million bovine udders and none was found to contain a tumor (cited in Povey and Osborne, 1969) and second done in Republic of South Africa where the occurrence of tumors in cattle over 40 years was followed (Bastianello, 1982). Out of 606 reported neoplasms the most common were squamous cell carcinomas of the eye and the vulva, whereas there were no mammary malignancies detected (Bastianello, 1982a). Similar surveys were performed in goats and sheep and no mammary tumors were identified (Bastianello, 1982b, Bastianello, 1982c). The Veterinary Diagnostic Laboratory at Oregon State University inspected 102 tumors in 100 goats; of these 7 were mammary adenocarcinomas (Löhr, 2012). One case of estrogen-dependent fibroadenoma growth was described in 2-month-old lamb mammary tissue (Dezfoulian et al., 2011). The benign tumors are common in woman and rats but only two reports were made in cattle (Mina et al., 1994, Tibault et al. 1997). Udders from 220 female goats were evaluated histologically, and three intraductal carcinomas were found, one of which had metastasized to the mammary lymph nodes (Singh and Iyer, 1972). There was one interesting case reported in Nubian buck, which was diagnosed with gynecomastia, mastitis, and mammary adenocarcinoma with active lactation, hyperplasia, and abscessation (Wooldridge et al., 1999).

Differential diagnoses for masses in the udder include mastitis, abscess, hematoma, and other conditions that may lead to misdiagnosis and removal of animals from herds, without proper examination. For this reason some of the cases of mammary tumors can get overlooked. Additionally, the question arises as to whether the primary tumor did arise within the interstitial tissue of the mammary gland, or in a subcutaneous location cranial to the gland, from which it could have invaded the mammary tissue. Nevertheless the incidence of mammary neoplasia in ruminants is still almost non existing.

\section{RISK FACTORS}

Due to the rare occurrence of mammary tumors in professional lactators, the risk factors and the biological behavior of mammary carcinomas are unknown. Epidemiological data support a role for hyperestrogenism in the genesis of human breast cancer. Ovarian hormones estrogen and progesterone are pivotal for the develop- 
Table 1: Reports of mammary tumors in cattle, goats and sheep Preglednica 1: Poročila o tumorjih mlečne žleze pri kravah, kozah in ovcah

\begin{tabular}{|c|c|c|c|}
\hline Species & Mammary cancer & Survey & Reference \\
\hline \multirow[t]{12}{*}{ Cow (Bos taurus) } & I & $0 / 418$ & Sweet et al., 1940 \\
\hline & l & 0/13 million & cited in Povey and Osborne, 1969 \\
\hline & fibrosarcoma & case report & Povey and Osborne, 1969 \\
\hline & l & $0 / 606$ & Bastianello, 1982a \\
\hline & carcinoma with metastasis & case report & Beamer and Simon, 1983 \\
\hline & fibrosarcoma & case report & Orr, 1984 \\
\hline & fibroma and fibrosarcoma & case reports & Ford et al., 1989 \\
\hline & carcinoma with metastasis & case report & Petrites-Murphy, 1992 \\
\hline & fibroadenoma & case report & Mina et al., 1994 \\
\hline & fibroadenoma & case report & Thibault et al., 1997 \\
\hline & secretory carcinoma & case report & Ohfuji, 2012 \\
\hline & comedocarcinoma & case report & Chandrashekar et al., 2012 \\
\hline \multirow[t]{4}{*}{ Goat (Capra hircus) } & intraductal carcinomas & $3 / 220$ & Singh and Iyer, 1972 \\
\hline & l & $0 / 21$ & Bastianello, 1982b \\
\hline & adenocarcinoma in male & case report & Wooldridge et al., 1999 \\
\hline & adenocarcinomas & $7 / 100$ & Löhr, 2012 \\
\hline \multirow[t]{5}{*}{ Sheep (Ovis aries) } & adenoma & case report & Ali, 1986 \\
\hline & l & $0 / 673$ & Bastianello, 1982c \\
\hline & fibroadenoma & case report & Gulbahar et al. 2007 \\
\hline & carcinoma & case report & McElroy and Bassett, 2010 \\
\hline & fibroadenoma & case report & Dezfoulian et al., 2011 \\
\hline
\end{tabular}

ment of mammary gland and are involved in breast cancer (Tanos et al. 2012). Estrogen is crucial for epithelial cell growth, while progesterone promotes lobulo-alveolar differentiation during pregnancy and lactation. More than $60 \%$ of breast cancers in women are of estrogen receptor positive type. Pregnancy shortens such exposure to estrogen. Evidence is fairly convincing that lactation reduces the risk of breast cancer among premenopausal women (Enger at al., 1997). The low rate of mammary tumors in cattle may be due to the high rate of pregnancies as increased parity shortens exposure to estrogen and high lactation demands give protection against mammary carcinoma. In humans, a completed pregnancy at a young age reduces woman's lifetime risk of breast cancer by up to $50 \%$. However, the mechanisms responsible for this protective effect remain unclear. Stem cells have been proposed to be the cells of origin for breast cancer. Siwko and colleagues showed in different mice models that the numbers of adult mammary stem cells decreases with early pregnancy (Siwko et al. 2008).

The dietary factors might explain the species differences, since lactation is evolutionary highly conserved process. However the species differ in diet regimes and in reproduction strategies. Diet low in fat and high in vegetable fibers is beneficial in protecting against breast cancer. Fruit and vegetable intake has been hypothesized to reduce the risk of breast cancer in humans. A recent meta-analysis of 14 cohort studies reported a statistically significant $11 \%$ reduced risk of breast cancer overall comparing high vs. low fruit and vegetable intake (Aune et al., 2012). On the contrary carnivores, like dogs or humans, eat a lot of meat and tend to be obese; these could be two major risk factors for development of mammary neoplasia (Perez-Alenza et al., 2000). Another risk is that carnivores intake more carcinogens through diet since they are higher on the food chain.

\section{CONCLUSION}

Laboratory mice are being used as model organisms for breast cancer, which can arise spontaneously or can be induced chemically, by tumor transplantation, viral infection and in transgenic and/or knockout mice. But rodents differ considerably in mammary gland development and types of breast cancer from women. Many 
mammary gland cancers in mice are induced by a virus or a chemical, thus are not good models for human breast cancer. Because of similarities between human and ruminant mammary gland morphology and the fact that the incidence of mammary cancer in cattle is minimal further delineation of ruminant mammary gland populations is of clinical importance. Using translational research there is a chance that understanding the processes occurring in mammary gland cells of bovine species will eventually provide clinical benefits for treatment of human breast cancer patients.

\section{REFERENCES}

Ali A.O. 1986. An Ovine Mammary Adenoma. Vet. Pathol., 23: 217-218

Aune D., Chan D.S., Vieira A.R., Rosenblatt D.A., Vieira R., Greenwood D.C., Norat T. 2012. Fruits, vegetables and breast cancer risk: a systematic review and meta-analysis of prospective studies. Breast Cancer Res. Treat., 134, 2: 479-493

Bastianello S.S. 1982a. A survey on neoplasia in domestic species over a 40-year period from 1935 to 1974 in the Republic of South Africa. I. Tumours occurring in cattle. Onderstepoort J. Vet. Res., 49, 4: 195-204

Bastianello S.S. 1982b. A survey on neoplasia in domestic species over a 40-year period from 1935 to 1974 in the Republic of South Africa. III. Tumours occurring in pigs and goats. Onderstepoort J. Vet. Res., 50, 1: 25-28

Bastianello S.S. 1982c. A survey on neoplasia in domestic species over a 40-year period from 1935 to 1974 in the Republic of South Africa. III. Tumours occurring in sheep. Onderstepoort J. Vet. Res., 49, 4: 205-209

Beamer P.D., Simona J. 1983. Mammary carcinoma in a cow. Vet. Pathol., 20: 509-510

Dezfoulian O., Asedian P., Sookhtehzari A., Kheradmand A. 2011. Estrogen-induced mammary fibroadenoma in a lamb: hormonal and immunohistochemical aspects. Iranian Journal of Veterinary Research, 12, 2: 163-166

Enger S.M., Ross R.K., Henderson B., Bernstein L. 1997. Breast feeding history, pregnancy experience and risk of breast cancer. Br. J. Cancer., 76, 1: 118-123

Ford T.S., Ross M.W., Acland H.M., Madison J.B. 1989. Primary teat neoplasia in two yearling heifers. J. Am. Vet. Med. Assoc., 195: 238-239

Hovey R.C., McFadden T.B., Akers R.M. 1999. Regulation of mammary gland growth and morphogenesis by the mammary fat pad: a species comparison. J. Mammary Gland Biol. Neoplasia, 4, 1: 53-68

Lim E., Wu D., Pal B., Bouras T., Asselin-Labat M. L., Vaillant F.,
Yagita H., Lindeman G.J., Smyth G.K., Visvader J.E. 2010. Transcriptome analyses of mouse and human mammary cell subpopulations reveal multiple conserved genes and pathways. Breast Cancer Research, 12, 2: R21

Löhr C.V. 2012. One Houndred Two Tumors in 100 Goats (1987-2011). Domestic Mammal Disease. Veterinary Pathology, 50, 4: 668-675

McElroy M.C, Bassett H.F. 2010. Mammary carcinoma in a ewe. J. Vet. Invest., 22: 1006-1007

McPherson C.M., Steel J.M., Dixon K. 2000. ABC of Breast Diseases. Breast cancer -epidemiology, risk factors, and genetics. Clinical review. BMJ., 321, 9

Megalhaes G.M., Silveira A.C.T., Maunari D.P., Alessi A.C. 2012. Behavior of CD44 receptors in mammary tumors of dogs. Open Journal of Veterinary Medicine. 2: 48-51

Mina R.B., Uchida K., Sakumi A., Yamaguchi R., Tateyama S., Ogawa H., Otsuka H. 1994. Mammary fibroadenoma in a young Holstein cow. J .Vet. Med. Sci., 56: 1171-1172

Munson L., Moresco A. 2007. Comparative pathology of mammary gland cancers in domestic and wild animals. Breast Disease, 28: 7-21

Ohfuji S. 2012. Case report. Secretory carcinoma of the mammary gland in an 8-year-old Holstein-Friesan dairy cow. Veterinary Quaterly, 32, 2: 113-115

Perez-Alenza M.D., Peña L., del Castillo N., Nieto A.I. 2000. Factors influencing the incidence and prognosis of canine mammary tumors. J. Small Anima Pract., 41: 287-291

Petrites-Murphy. 1992. Mammary carcinoma with peritoneal metastasis in cow. Vet. Pathol., 129: 552-553

Povey R.C., Osborne A.D. 1969. Mammary gland neoplasia in the cow. Path. Vet., 6: 502-512

Sweet W.W., Matthews C.A., Graves R.R. 1940. Extreme rarity of cancer in cow's udder. J. Dairy Sci., 23: 437-446

Siwko S.K., Dong J., Lewis M.T., Liu H., Hilsenbeck S.G., Li Y. 2008. Evidence that an early pregnancy causes a persistent decrease in the number of functional mammary epithelial stem cells - implications for pregnancy-induced protection against breast cancer. Stem Cells., 26, 12: 3205-3209

Tanos T., Rojo L.J., Echeverria P., Brisken C. 2012. ER and PR signaling nodes during mammary gland development. Breast Cancer Res., 14, 4: 210

Thibault S., Mikaelian I., Daubreuil P., Drolet P., Couture Y. 1997. Mammary fibroadenoma in a heifer. Can. Vet. J., 38: 785-786

Yavuz Gaulbahar M., Guvenc T., Yarim M., Kabak Y.B., Sozgen Y. 2007. Mammary fibroadenoma in a lamb. J. Vet. Sci., 8, 4: $423-425$

Wooldridge A.A., Gill M.S., Lemarchand T., Eilts B., Taylor H.W., Otterson T. 1999. Gynecomastia and mammary gland adenocarcinoma in a Nubian buck. Can. Vet. J., 40: 663-665 